\title{
Kjønnsforskjeller i utredning og behandling av hjerteinfarkt
}

\begin{abstract}
BAKGRUNN Tidligere studier har vist at det er kjønnsforskjeller i utredning og behandling ved hjerteinfarkt, til tross for at internasjonale retningslinjer anbefaler lik behandling av kvinner og menn. Vi har undersøkt om det forelå slike forskjeller i Norge.
\end{abstract}

MATERIALE OG METODE Alle pasienter innlagt i norske sykehus med hjerteinfarkt fra 1.1. 2013 til 31.12. 2014 og registrert i Norsk hjerteinfarktregister ble inkludert. Data fra registeret ble benyttet til å analysere forskjeller i utredning, behandling, komplikasjoner og overlevelse hos kvinner og menn i ulike aldersgrupper.

RESULTATER Totalt 26447 hjerteinfarkt ble registrert i Norsk hjerteinfarktregister i 2013-14. Færre kvinner enn menn ble utredet med koronar angiografi. Ved funn av koronare stenoser ble perkutan koronar intervensjon (PCI) utført i tilnærmet samme grad hos begge kjønn. Kvinner ble i mindre grad enn menn anbefalt sekundærprofylaktisk medikasjon. Det forelå ingen større forskjeller i forekomsten av komplikasjoner i forløpet etter hjerteinfarkt eller i overlevelse mellom kvinner og menn.

FORTOLKNING Færre kvinner enn menn ble utredet med koronar angiografi ved akutt hjerteinfarkt og kvinner fikk sjeldnere enn menn anbefalt sekundærprofylaktisk medikasjon. Årsaken til kjønnsforskjellene er ikke kjent, men tilleggssykdommer og mulig større risiko for bivirkninger hos kvinner kan være medvirkende faktorer. Ulike oppfatninger hos behandlende leger kan også ha hatt betydning.

Hvert år blir ca. 13000 nordmenn innlagt med akutt hjerteinfarkt i norske sykehus (1). Flere studier har vist at kvinner kan ha mindre klare symptomer og kliniske funn, at de har lengre tidsforsinkelse til behandling, sjeldnere gjennomgår invasiv utredning og får færre sekundærprofylaktiske medikamenter ved utskrivning enn menn (2-13). Både korttids- og langtidsoverlevelsen etter hjerteinfarkt er betydelig forbedret de siste tiårene hos både kvinner og menn, men enkelte studier har vist dårligere overlevelse hos kvinner, spesielt ved ST-elevasjonsinfarkt (14-21). I Norge har det også vært påvist kjønnsforskjeller når det gjelder behandling av pasienter med hjerteinfarkt (22, 23). Europeiske retningslinjer for behandling av hjerteinfarkt anbefaler at man ikke skiller mellom kvinner og menn i utredning og behandling (24-26).

Basert på data fra Norsk hjerteinfarktregister har vi undersøkt om det fortsatt forelå forskjeller i utredning, behandling, komplikasjoner og overlevelse mellom kvinner og menn med ST-elevasjonsinfarkt og med ikkeST-elevasjonsinfarkt innlagt i norske sykehus i perioden 2013-14.

\section{Materiale og metode}

Alle pasienter med diagnosen akutt hjerteinfarkt innlagt $\mathrm{i}$ alle norske sykehus fra 1.1. 2013 til 31.12. 2014 og registrert i Norsk hjerteinfarktregister ble inkludert i denne studien. Kun pasienter med norsk fødselsnummer ble inkludert. Primærinnleggelser og overflyttinger ble registrert separat ved hvert sykehus, men disse ble på nasjonalt nivå koblet sammen til ett hjerteinfarktforløp.

Registrering av alle pasienter innlagt $\mathrm{i}$ norske sykehus med akutt hjerteinfarkt i Norsk hjerteinfarktregister er lovpålagt, jf. hjerte- og karregisterforskiften $\S 2-1$ (27). Registreringen krever ikke pasientsamtykke i henhold til helseregisterloven $\S 8$ (28). Registeret inneholder opplysninger om kjønn, alder, kjente risikofaktorer, tidligere sykdommer og medisiner, symptomer og kliniske funn ved innkomst og om utredning, behandling og komplikasjoner under oppholdet samt medisiner ved utskrivning fra sykehus. Tidspunktene for symptomdebut, for ankomst første sykehus og for invasiv behandling ble også registrert. Som tidspunkt for invasiv behandling ble tidspunktet for ballongdilatasjon eller direkte innsetting av stent i koronararterie benyttet.

Registrering og kvalitetssikring av opplysninger i Norsk hjerteinfarktregister er beskrevet tidligere (1). Dødstidspunktet oppdateres i registeret fra det sentrale folkeregister.

Norsk hjerteinfarktregister følger den tredje universelle definisjonen av hjerteinfarkt for diagnosen akutt hjerteinfarkt (29). Diagnosen er basert på stigning og/eller fall i troponinverdi og ett av følgende tilleggskriterier: iskemiske symptomer, ny ST-elevasjon/ ST-depresjon/T-inversjon/venstre grenblokk, utvikling av patologisk Q-bølge, visuell frem-

\section{Jarle Jortveit}

jarle.jortveit@sshf.no

Medisinsk avdeling

Sørlandet sykehus, Arendal

Ragna Elise Støre Govatsmark

Norsk hjerteinfarktregister

St. Olavs hospital

\section{Jørund Langørgen}

Hjerteavdelingen

Haukeland universitetssykehus

Torstein Hole

Klinikk for medisin

Helse Møre og Romsdal

Jan Mannsverk

Hjertemedisinsk avdeling

Universitetssykehuset Nord-Norge

Siv Olsen

Medisinsk klinikk

Universitetssykehuset Nord-Norge, Harstad

\section{Cecilie Risøe}

Kardiologisk avdeling

Oslo universitetssykehus, Rikshospitalet

Sigrun Halvorsen

Oslo universitetssykehus, Ullevål

og

Universitetet i Oslo

> Se også side 1181

e-tab 4 og e-tab 5 finnes i Tidsskriftets elektroniske utgaver

Engelsk oversettelse på www.tidsskriftet.no

\section{HOVEDBUDSKAP}

Færre kvinner enn menn ble rammet av hjerteinfarkt i Norge i 2013-14

Gjennomsnittsalderen ved hjerteinfarkt var høyere hos kvinner enn hos menn

Færre kvinner enn menn med hjerteinfarkt ble utredet med koronar angiografi

Kvinner fikk i mindre grad enn menn forskrevet sekundærprofylaktiske medisiner etter hjerteinfarkt 
Tabell 1 Karakteristika hos pasienter med hjerteinfarkt innlagt i norske sykehus 2013-14

\begin{tabular}{ccc} 
& $\begin{array}{c}\text { ST-elevasjonsinfarkt } \\
\mathrm{n}=6386\end{array}$ \\
\cline { 1 - 2 } $\begin{array}{c}\text { Kvinner } \\
\mathrm{n}=1862\end{array}$ & $\begin{array}{c}\text { Menn } \\
\mathrm{n}=4524\end{array}$ & \\
\cline { 1 - 2 } Antall $(\%)$ & Antall $(\%)$ & P-verdi
\end{tabular}

\begin{tabular}{ccc}
\multicolumn{2}{c}{ Ikke-ST-elevasjonsinfarkt } \\
$\mathrm{n}=17558$
\end{tabular}

Diabetes mellitus

$\begin{array}{lrrrrrrrrrrr}<50 a ̊ r & 15 & (15) & 44 & (8) & 0,06 & 29 & (15) & 81 & (12) & 0,37 \\ 50-59 a ̊ r & 38 & (18) & 111 & (10) & <0,001 & 90 & (19) & 289 & (18) & 0,01 & \\ 60-69 a ̊ r & 48 & (12) & 159 & (12) & 0,36 & 222 & (22) & 547 & (21) & 0,64 \\ 70-79 a ̊ r & 65 & (14) & 127 & (14) & 0,54 & 316 & (21) & 644 & (25) & 0,04 \\ \geq 80 a ̊ r & 114 & (17) & 102 & (16) & 0,73 & 689 & (19) & 725 & (22) & 0,01\end{array}$

Hypertensjon

\begin{tabular}{|c|c|c|c|c|c|c|c|c|c|c|}
\hline$<50 \mathrm{ar}$ & 21 & (21) & 71 & (13) & 0,16 & 46 & (24) & 146 & (22) & 0,84 \\
\hline $50-59$ år & 74 & (34) & 260 & (23) & 0,002 & 176 & (37) & 516 & (31) & 0,10 \\
\hline $60-69$ år & 157 & (38) & 469 & (35) & 0,16 & 464 & (46) & 1190 & (45) & 0,86 \\
\hline $70-79$ år & 218 & (48) & 379 & (43) & 0,39 & 831 & (56) & 1433 & (55) & 0,44 \\
\hline$\geq 80$ år & 365 & (54) & 285 & (43) & $<0,001$ & 2191 & (61) & 1737 & (54) & $<0,001$ \\
\hline
\end{tabular}

Røyking ${ }^{1}$

\begin{tabular}{|c|c|c|c|c|c|c|c|c|c|c|}
\hline < $50 \mathrm{ar}$ & 78 & (76) & 396 & (74) & 0,18 & 134 & (70) & 469 & (71) & 0,67 \\
\hline $50-59$ år & 180 & (83) & 807 & (73) & 0,01 & 344 & (73) & 1161 & (71) & 0,23 \\
\hline $60-69$ år & 309 & (75) & 949 & (71) & 0,07 & 695 & (68) & 1886 & (71) & 0,18 \\
\hline $70-79$ år & 253 & (56) & 528 & (60) & 0,06 & 830 & (56) & 1704 & (65) & $<0,001$ \\
\hline$\geq 80$ år & 186 & (27) & 350 & (53) & $<0,001$ & 1050 & (29) & 1783 & (55) & $<0,001$ \\
\hline
\end{tabular}

Statinbehandlet dyslipidemi

\begin{tabular}{|c|c|c|c|c|c|c|c|c|c|c|}
\hline < $50 \mathrm{år}$ & 14 & (14) & 65 & (12) & 0,91 & 30 & $(16)$ & 170 & (26) & 0,01 \\
\hline $50-59$ år & 39 & (18) & 199 & (18) & 1,00 & 146 & (31) & 573 & (35) & 0,07 \\
\hline $60-69$ år & 81 & (20) & 350 & (26) & 0,02 & 397 & (39) & 1206 & (45) & 0,002 \\
\hline $70-79$ år & 115 & (25) & 249 & (28) & 0,09 & 646 & $(44)$ & 1370 & (53) & $<0,001$ \\
\hline$\geq 80$ år & 150 & (22) & 189 & (29) & 0,01 & 1264 & (35) & 1466 & (45) & $<0,001$ \\
\hline
\end{tabular}

1 Tidligere røyker eller nåværende røyker. Røykestatus var ikke registrert hos 3080 (12,9\%)

For de andre variablene var andelen ukjent $<1,2 \%$.

stilling av ny myokardskade eller påvisning av intrakoronar trombe ved angiografi eller obduksjon (29).

Hjerteinfarkt med symptomdebut $\leq 28$ dager før sykehusinnleggelsen ble registrert som akutt hjerteinfarkt i henhold til den internasjonale statistiske klassifikasjonen av sykdommer og beslektede helseproblemer (ICD10). Troponin var foretrukne biokjemiske hjerteinfarktmarkør. Referansegrensene (99prosentilen) for troponin I er avhengig av produsent. For troponin T ble særnorsk tradisjon med diagnostisk grense $\geq 30 \mathrm{ng} / \mathrm{l}$ benyttet til og med mai 2013. Fra 1.6. 2013 ble den internasjonale grensen for diagnosen hjerteinfarkt ved troponin $\mathrm{T}>14 \mathrm{ng} / \mathrm{l}$ anbefalt også i Norge (30).

Alle hjerteinfarkt ble klassifisert som type
1-5, der type 1 ble definert som et spontant hjerteinfarkt relatert til iskemi forårsaket av plakkfissur, -erosjon eller -ruptur eller av disseksjon med intraluminal trombe. Type 2-infarkt ble definert som sekundært til iskemi forårsaket av ubalanse mellom myokards oksygenbehov og tilførsel, type 3infarkt som kardial død antatt relatert til iskemi, type 4-infarkt som relatert til invasiv 
Tabell 2 Tidsforløp ved hjerteinfarkt hos pasienter innlagt i norske sykehus 2013-14

ST-elevasjonsinfarkt

\begin{tabular}{|c|c|c|c|c|}
\hline \multicolumn{2}{|c|}{ Kvinner } & \multicolumn{2}{|c|}{ Menn } & \\
\hline $\begin{array}{c}\text { Timer } \\
\text { (median) }\end{array}$ & $\begin{array}{c}\text { (nedre, } \\
\text { øre kvartil) }\end{array}$ & $\begin{array}{c}\text { Timer } \\
\text { (median) }\end{array}$ & $\begin{array}{c}\text { (nedre, } \\
\varnothing v r e \text { kvartil) }\end{array}$ & P-verdi \\
\hline
\end{tabular}

Ikke-ST-elevasjonsinfarkt

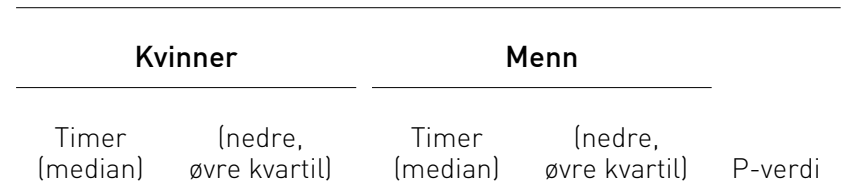

Tid fra symptomdebut til innleggelse første sykehus ${ }^{1}$

$\begin{array}{lllllllllll}<50 \text { år } & 2,3 & (1,5,2,3) & 2,0 & (1,3,3,8) & 0,48 & 3,0 & (1,8,7,8) & 3,3 & (1,9,7,0) & 0,28 \\ 50-59 a ̊ r & 2,4 & (1,7,4,3) & 2,0 & (1,4,3,7) & 0,25 & 3,3 & (1,9,8,0) & 3,5 & (2,0,7,0) & 0,84 \\ 60-69 a ̊ r & 2,3 & (1,5,3,5) & 2,0 & (1,5,4,0) & 0,49 & 4,0 & (2,1,7,8) & 3,5 & (2,0,7,5) & 0,10 \\ 70-79 a ̊ r & 3,0 & (1,9,5,2) & 2,0 & (1,5,4,7) & 0,002 & 3,8 & (2,0,6,9) & 3,7 & (2,0,7,4) & 0,81 \\ \geq 80 \mathrm{a} r & 3,4 & (1,8,6,4) & 3,0 & (1,7,5,6) & 0,13 & 3,8 & (2,0,7,8) & 3,7 & (2,0,7,0) & 0,68\end{array}$

Tid fra innleggelse første sykehus til koronar angiografi ${ }^{2}$

\begin{tabular}{|c|c|c|c|c|c|c|c|c|c|c|}
\hline < $50 \mathrm{ar}$ & 1,0 & $(0,4-3,9)$ & 0,7 & $(0,4-1,8)$ & 0,07 & 37 & $(17,0-62,5)$ & 34 & $(17,2-61,0)$ & 0,62 \\
\hline $50-59$ år & 0,8 & $(0,4-2,7)$ & 0,7 & $(0,4-1,9)$ & 0,09 & 41 & $(16,8-69,0)$ & 41 & $(18,6-65,2)$ & 0,49 \\
\hline $60-69$ år & 0,7 & $(0,4-2,1)$ & 0,7 & $(0,4-2,3)$ & 0,87 & 49 & $(25,4-81,9)$ & 45 & $(22,8-72,4)$ & $<0,001$ \\
\hline $70-79$ år & 0,9 & $(0,6-5,4)$ & 0,8 & $(0,6-3,3)$ & 0,36 & 51 & $(26,5-93,8)$ & 53 & $(26,0-89,2)$ & 0,87 \\
\hline$\geq 80$ år & 1,1 & $(0,5-2,4)$ & 0,7 & $(0,4-2,7)$ & 0,18 & 71 & $(35,7-119,1)$ & 58 & $(26,9-108,2)$ & $<0,001$ \\
\hline
\end{tabular}

1 Registrering av tidsforløpet fra symptomdebut til innleggelse manglet ved 660 (11,7\%) ST-elevasjonsinfarkt og 4590 (32,5\%) ikke-ST-elevasjonsinfarkt

${ }^{2}$ Registrering av tidsforløpet fra innleggelse ved første sykehus til koronar angiografi manglet ved 60 (1,2\%) ST-elevasjonsinfarkt og 474 (5,9\%) ikke-ST-elevasjonsinfarkt

koronar prosedyre eller stenttrombose og type 5-infarkt som relatert til koronar kirurgi.

Siden europeiske retningslinjer ikke skiller klart mellom de ulike hjerteinfarkttypene når det gjelder behandling, har vi valgt å presentere resultatene for alle typene samlet. Hjerteinfarktene ble også klassifisert som ST-elevasjonsinfarkt eller ikke-ST-elevasjonsinfarkt basert på forandringer i innkomst-EKG: STelevasjonsinfarkt ved ny ST-segmentelevasjon eller nyoppstått venstre grenblokk, ikkeST-elevasjonsinfarkt ved normalt EKG, STdepresjon, T-inversjon eller andre ST-T-forandringer.

Kontinuerlige variabler er presentert som gjennomsnitt $\pm \mathrm{SD}$ (standarddeviasjon) eller median (nedre, øvre kvartil), forskjeller mellom grupper er analysert med t-test eller ikke-parametriske tester. Kategoriske data er presentert som antall og prosentandel, forskjeller mellom grupper er analysert med khikvadrattest. Overlevelse er presentert med Kaplan-Meier-kurver. Alle pasienter ble fulgt til død eller til 30.6. 2015. Forskjeller i overlevelse mellom kvinner og menn i ulike aldersgrupper er analysert med Cox' regresjonsanalyse og er presentert som ujustert hasardratio (HR) med $95 \%$ konfidensintervall (KI). Ved alle analyser er en p-verdi
$<0,05$ vurdert som statistisk signifikant. Data er analysert i statistikkprogrammene SPSS versjon 21 og STATA versjon 14 .

Sammenstilling og publisering av opplysninger fra registeret er hjemlet $i$ hjerte- og karregisterforskriften $\S 3-1$ og krever ikke godkjenning fra regional etisk komité.

\section{Resultater}

Kliniske karakteristika

Det ble registrert 26447 hjerteinfarkt fordelt på 24820 unike pasienter registrert i Norsk hjerteinfarktregister i perioden 2013-14. Dette tilsvarer for $201383 \%$ og for 2014 $88 \%$ av alle hjerteinfarkt registrert i Norsk pasientregister. Andelen type 1-hjerteinfarkt var $81 \%(n=21500)$. Av alle registrerte hjerteinfarkt ble totalt 6539 (25\%) klassifisert som ST-elevasjonsinfarkt og 19014 (72\%) som ikke-ST-elevasjonsinfarkt. Totalt 894 hjerteinfarkt (3\%) var ikke klassifiserbare.

Andelen kvinner var $29 \%$ for ST-elevasjonsinfarkt og 39\% for ikke-ST-elevasjonsinfarkt. Kjønnsfordelingen ved type 1-hjerteinfarkt var ikke signifikant forskjellig fra kjønnsfordelingen ved alle hjerteinfarkt samlet. Gjennomsnittsalderen ved hjerteinfarkt var 77,2 år ( \pm 13 år) for kvinner og 69,4 år ( \pm 14 år) for menn. Både kvinner med
ST-elevasjonsinfarkt $(\mathrm{p}<0,001)$ og kvinner med ikke-ST-elevasjonsinfarkt $(\mathrm{p}<0,001)$ var eldre enn mennene.

Kliniske karakteristika for kvinner og menn i ulike aldergrupper fremgår av tabell 1 . Røyking var vanligere hos de eldste mennene enn hos kvinnene på samme alder. Det forelå få kjønnsforskjeller vedrørende diabetes mellitus og hypertensjon, men kvinner i aldersgruppen 50-59 år hadde høyere forekomst av diabetes mellitus enn menn i samme aldersgruppe, og færre kvinner enn menn over 60 år brukte statiner ved innleggelsen.

Det var liten kjønnsforskjell i tidsforsinkelsen fra symptomdebut til sykehusinnleggelse, men registrering av tidsforløpet manglet ved mange hjerteinfarkt (tab 2).

\section{Behandling}

Koronar angiografi ble utført ved 5517 $(84 \%)$ av ST-elevasjonsinfarktene og ved 10345 (54\%) av ikke-ST-elevasjonsinfarktene. Færre kvinner enn menn ble angiografert ved ikke-ST-elevasjonsinfarkt (fig 1). Kjønnsforskjellen var fortsatt til stede hvis hjerteinfarkt type 2-5 ble ekskludert fra analysen og også ved justering for alder innen hver aldersgruppe (data ikke vist).

Ved ST-elevasjonsinfarkt forelå det ingen kjønnsforskjell hos pasienter under 80 år. 


\section{ST-elevasjonsinfarkt}

Andel hjerteinfarkt utredet med koronar angiografi (\%)

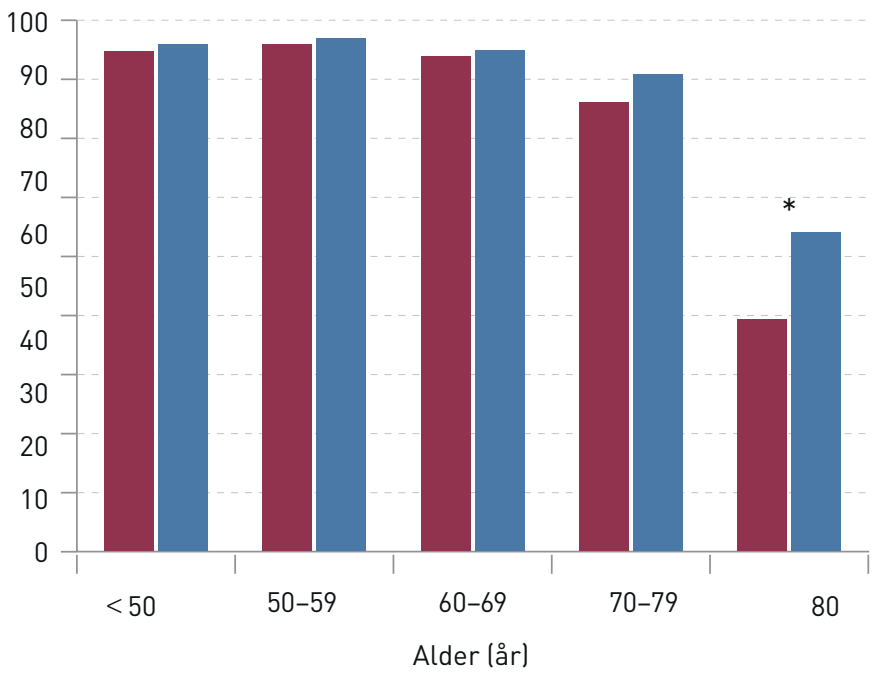

\section{ST-elevasjonsinfarkt}

Andel hjerteinfarkt behandlet med $\mathrm{PCl}$ ved koronar stenose (\%)

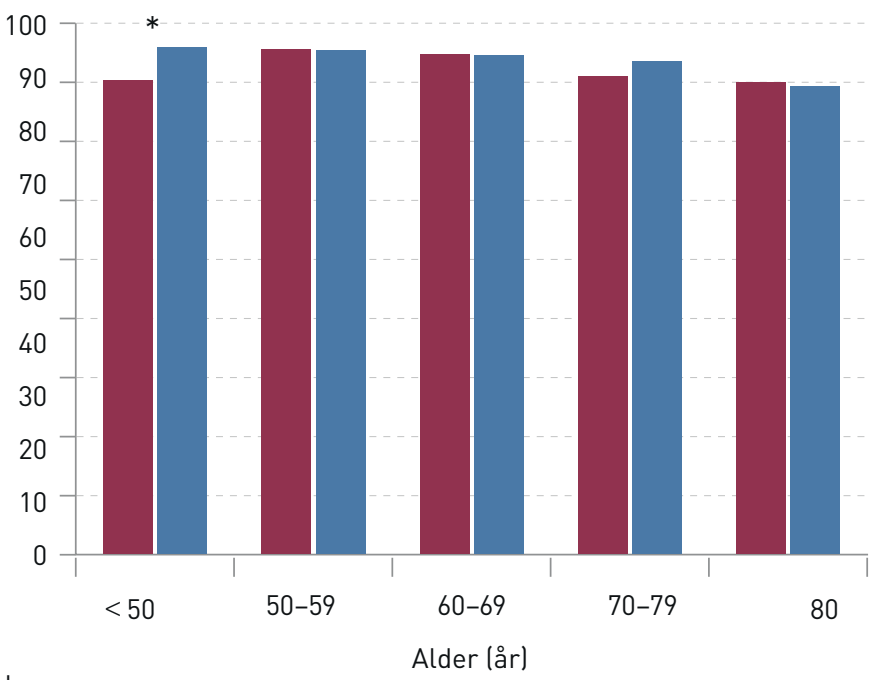

\section{Ikke-ST-elevasjonsinfarkt}

Andel hjerteinfarkt behandlet med $\mathrm{PCl}$ ved koronar stenose (\%)

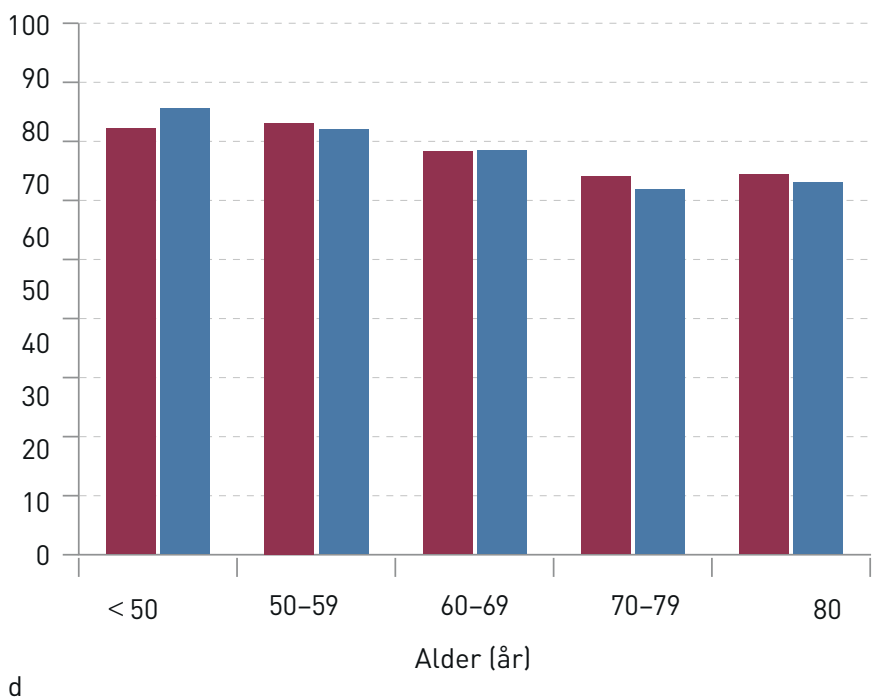

Andel hjerteinfarkt utredet med koronar angiografi (\%)

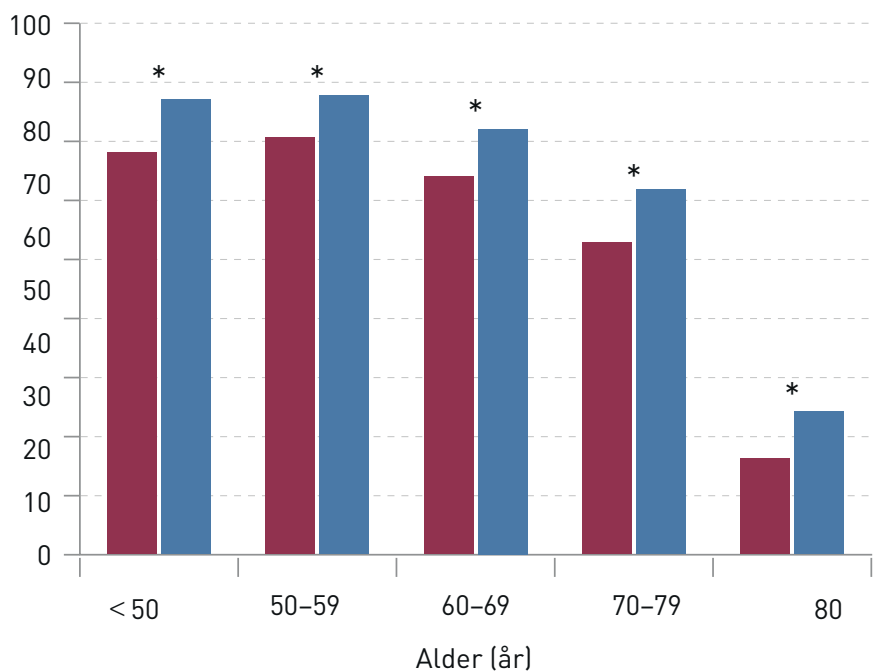

*Signifikant forskjell mellom kvinner og menn innen samme aldersgruppe

Figur 1 Andel hjerteinfarkt utredet med koronar angiografi (a, c) og andel med perkutan koronar intervensjon (PCI) (b, d) ved koronar stenose hos pasienter innlagt i norske sykehus i $2013-14$

Færre kvinner enn menn fikk påvist signifikant koronar stenose ved koronar angiografi både ved ST-elevasjonsinfarkt og ved ikkeST-elevasjonsinfarkt, men forskjellen var numerisk mye større ved ikke-ST-elevasjonsinfarkt. Hos pasienter med påvist signifikant koronar stenose var det ingen kjønns- forskjell i andelen som fikk utført perkutan koronar intervensjon (PCI), med unntak av en noe lavere andel hos kvinner $<50$ år med ST-elevasjonsinfarkt. For de fleste aldersgrupper forelå det ingen kjønnsforskjell i tidsforsinkelsen fra innleggelse til revaskularisering (tab 2)
Bruken av sekundærprofylaktiske medikamenter som blodplatehemmere (acetylsalisylsyre og adenosindifosfatreseptorhemmere (ADP-reseptorhemmere)), betablokkere, renin-angiotensin-system-hemmere (angiotensinkonvertasehemmere (ACE-hemmere))/ angiotensin II-reseptorhemmere (AII-resep- 
Tabell 3 Medikamenter ved utskrivning hos pasienter med hjerteinfarkt innlagt i norske sykehus 2013-14

\begin{tabular}{cc}
\multicolumn{2}{c}{$\begin{array}{c}\text { ST-elevasjonsinfarkt } \\
\mathrm{n}=5932\end{array}$} \\
\cline { 1 - 2 } $\begin{array}{c}\text { Kvinner } \\
\mathrm{n}=1650\end{array}$ & $\begin{array}{c}\text { Menn } \\
\mathrm{n}=\mathbf{4} 282\end{array}$ \\
\cline { 1 - 1 } Antall (\%) & Antall (\%) P-verdi
\end{tabular}

\begin{tabular}{ccc}
\multicolumn{2}{c}{ Ikke-ST-elevasjonsinfarkt } \\
$\mathrm{n}=17757$
\end{tabular}

Blodplatehemmer (minst én)

\begin{tabular}{|c|c|c|c|c|c|c|c|c|c|c|}
\hline 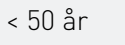 & 95 & $(96,9)$ & 517 & $(98,5)$ & 0,29 & 179 & $(90,9)$ & 653 & $(96,5)$ & 0,001 \\
\hline $50-59$ år & 207 & $(99,0)$ & 1083 & $(98,9)$ & 0,83 & 458 & $(94,8)$ & 1656 & $(97,9)$ & $<0,001$ \\
\hline $60-69$ år & 400 & $(98,3)$ & 1280 & $(98,7)$ & 0,64 & 993 & $(96,2)$ & 2659 & $(97,4)$ & 0,08 \\
\hline $70-79$ år & 389 & $(95,8)$ & 796 & $(98,6)$ & 0,001 & 1423 & $(92,9)$ & 2518 & $(94,9)$ & 0,002 \\
\hline$\geq 80$ år & 491 & $(92,6)$ & 522 & $(93,5)$ & 0,56 & 2980 & $(83,5)$ & 2758 & $(86,3)$ & 0,004 \\
\hline
\end{tabular}

To ulike blodplatehemmere

$\begin{array}{lrrrrrrrrrrr}<50 a ̊ r & 86 & (87,8) & 498 & (94,9) & 0,02 & 159 & (80,7) & 593 & (87,6) & 0,04 \\ 50-59 a ̊ r & 200 & (95,7) & 1035 & (94,5) & 0,69 & 399 & (82,6) & 1435 & (84,8) & 0,35 \\ 60-69 a ̊ r & 374 & (91,9) & 1207 & (93,1) & 0,19 & 805 & (78,0) & 2241 & (82,1) & 0,02 \\ 70-79 a ̊ r & 353 & (86,9) & 723 & (89,6) & 0,14 & 1066 & (69,6) & 1970 & (74,3) & <0,001 \\ \geq 80 & a ̊ r\end{array}$

\section{Statiner}

\begin{tabular}{|c|c|c|c|c|c|c|c|c|c|c|}
\hline$<50$ år & 87 & $(88,8)$ & 494 & $(94,1)$ & 0,12 & 158 & $(80,2)$ & 623 & $(92,0)$ & $<0,001$ \\
\hline $50-59$ àr & 190 & $(90,9)$ & 1034 & $(94,4)$ & 0,14 & 418 & $(86,5)$ & 1571 & $(92,8)$ & $<0,001$ \\
\hline $60-69$ år & 381 & $(93,6)$ & 1232 & $(95,0)$ & 0,50 & 893 & $(86,5)$ & 2516 & $(92,2)$ & $<0,001$ \\
\hline $70-79$ år & 359 & $(88,4)$ & 748 & $(92,7)$ & 0,01 & 1272 & $(83,1)$ & 2334 & $(88,0)$ & $<0,001$ \\
\hline$\geq 80$ år & 351 & $(66,2)$ & 437 & $(78,3)$ & $<0,001$ & 2012 & $(56,4)$ & 2193 & $(68,7)$ & $<0,001$ \\
\hline
\end{tabular}

\section{Betablokker}

$\begin{array}{lrrrrrrrrrrr}<50 a ̊ r & 76 & (77,6) & 422 & (80,4) & 0,72 & 120 & (60,9) & 483 & (71,3) & 0,01 \\ 50-59 a ̊ r & 166 & (79,4) & 902 & (82,4) & 0,28 & 342 & (70,8) & 1298 & (76,7) & 0,02 \\ 60-69 a ̊ r & 311 & (76,4) & 1067 & (82,3) & 0,03 & 740 & (71,7) & 2167 & (79,4) & <0,001 \\ 70-79 a ̊ r & 322 & (79,3) & 662 & (82,0) & 0,21 & 1196 & (78,1) & 2126 & (80,2) & 0,28 \\ \geq 80 a ̊ r & 401 & (75,7) & 429 & (76,9) & 0,54 & 2690 & (75,4) & 2442 & (76,5) & 0,52\end{array}$

\section{ACE-/All-reseptorhemmer}

\begin{tabular}{|c|c|c|c|c|c|c|c|c|c|c|}
\hline < 50 år & 48 & $(49,0)$ & 290 & $(55,2)$ & 0,46 & 64 & $(32,5)$ & 258 & $(38,1)$ & 0,15 \\
\hline $50-59$ år & 133 & $(63,6)$ & 637 & $(58,2)$ & 0,29 & 193 & $(40,0)$ & 749 & $(44,3)$ & 0,16 \\
\hline 60-69 år & 239 & $(58,7)$ & 837 & $(64,5)$ & 0,08 & 486 & $(47,1)$ & 1458 & $(53,4)$ & 0,002 \\
\hline $70-79$ år & 240 & $(59,1)$ & 507 & $(62,8)$ & 0,19 & 825 & $(53,9)$ & 1585 & $(59,8)$ & $<0,001$ \\
\hline$\geq 80$ år & 292 & $(55,1)$ & 311 & $(55,7)$ & 0,60 & 1769 & $(49,6)$ & 1535 & $(48,1)$ & 0,42 \\
\hline
\end{tabular}


ST-elevasjonsinfarkt

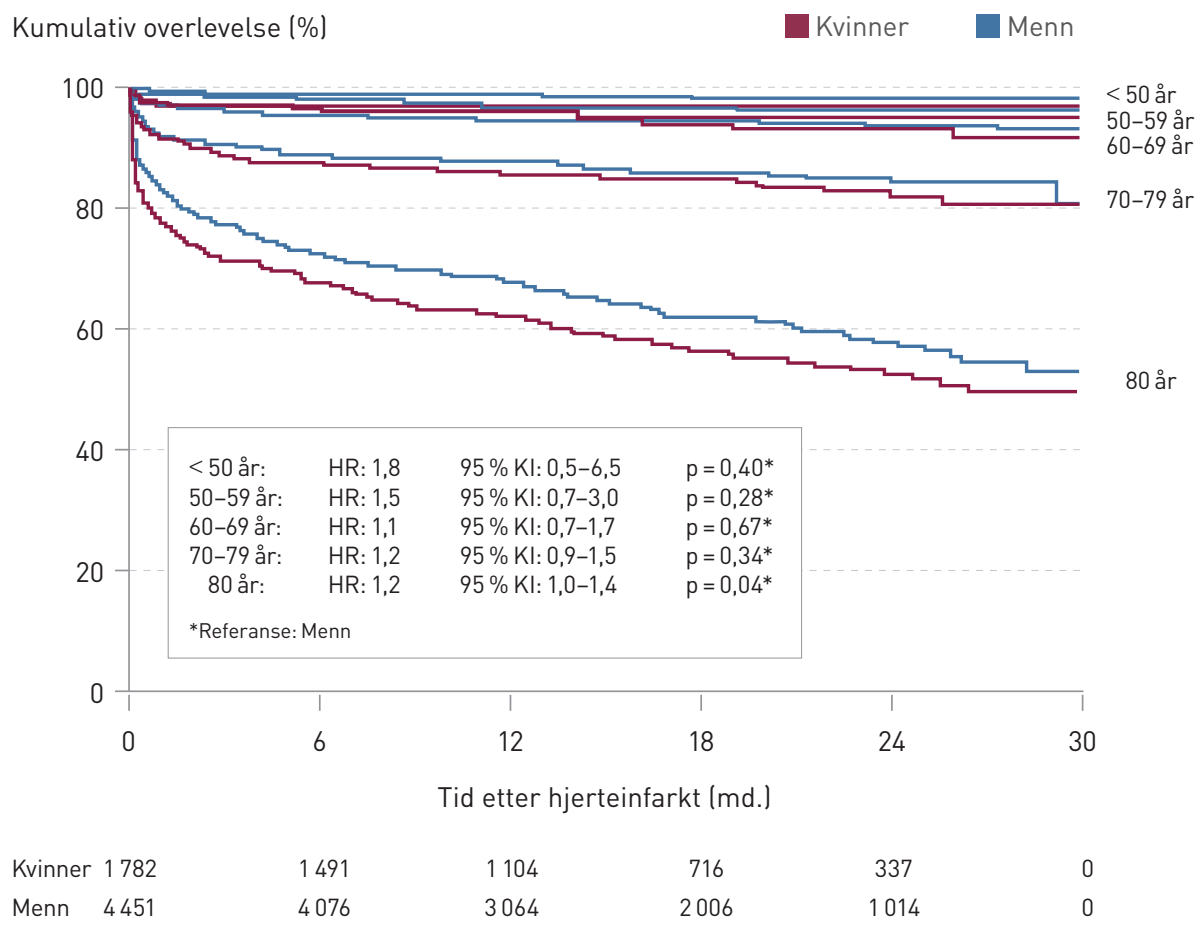

Ikke-ST-elevasjonsinfarkt

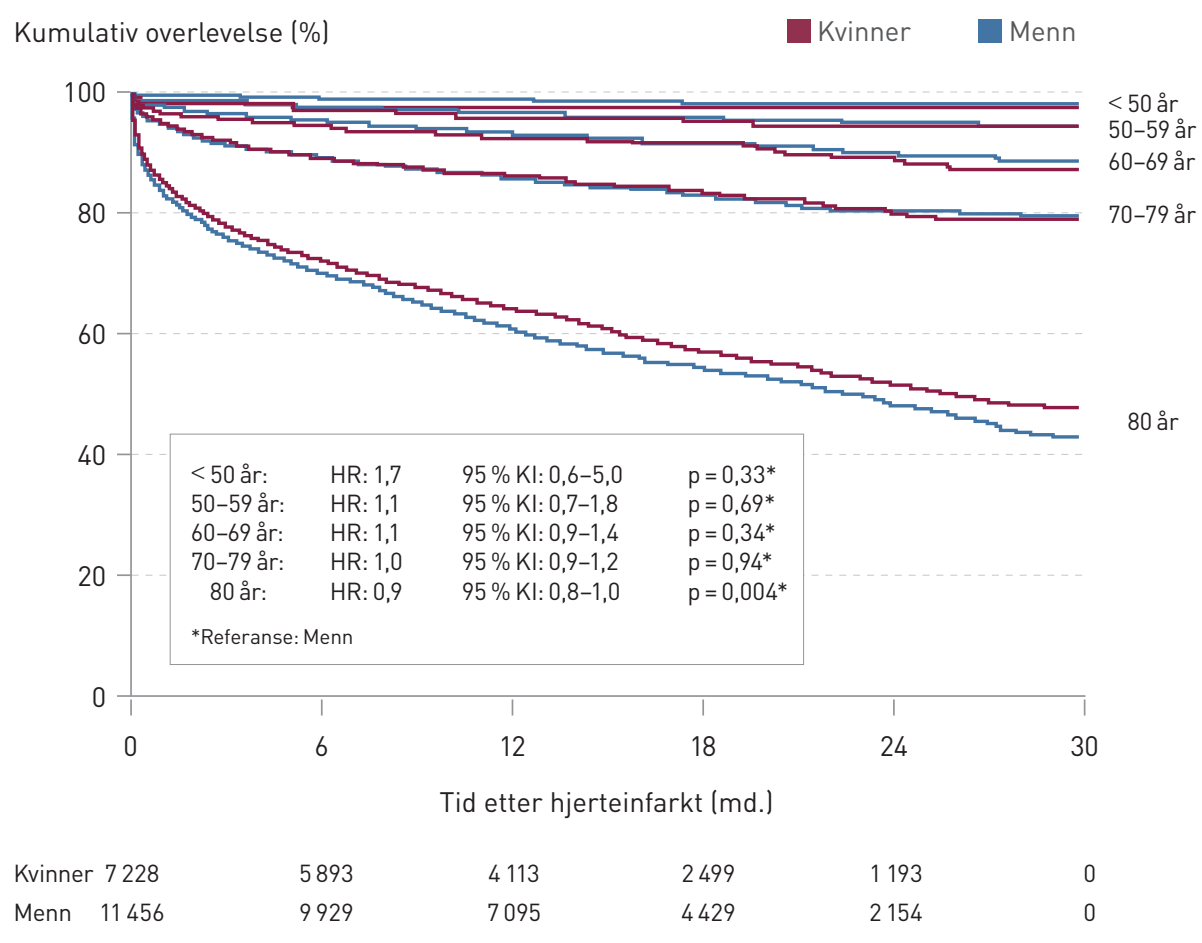

b

Figur 2 a, b) Kumulativ overlevelse etter hjerteinfarkt hos pasienter innlagt i norske sykehus 2013-14 torhemmere)) og statiner hos pasienter utskrevet i live er presentert i tabell 3. Færre kvinner enn menn med ikke-ST-elevasjonsinfarkt ble utskrevet med sekundærprofylaktiske medikamenter, spesielt statiner. Tilsvarende funn ble gjort når type 1-hjerteinfarkt ble analysert separat (e-tab 4). Det forelå ingen kjønnsforskjeller i bruken av antikoagulasjonsmedisiner ved utskrivning (data ikke vist).

\section{Komplikasjoner}

Hjertesvikt var hyppigste komplikasjon til hjerteinfarkt og var vanligst hos de eldste pasientene (e-tab 5). Noen flere menn enn kvinner opplevde ventrikkelflimmer/-takykardi de første to døgnene etter infarktet, ellers forelå det i liten grad kjønnsforskjeller i forekomsten av komplikasjoner etter hjerteinfarkt.

\section{Overlevelse}

Kumulativ overlevelse etter ST-elevasjonsinfarkt og etter ikke-ST-elevasjonsinfarkt hos kvinner og menn i ulike aldersgrupper er fremstilt i figur 2. Median oppfølgingstid var 443 dager (nedre kvartil 244, øvre kvartil 662). Det var ingen signifikante forskjeller i overlevelse mellom kvinner og menn $<80$ år.

Kvinner $\geq 80$ år hadde bedre overlevelse enn menn ved ikke-ST-elevasjonsinfarkt (ujustert HR 0,9, $95 \% \mathrm{KI} 0,8-1,0, \mathrm{p}=0,004$; aldersjustert HR 0,8 , $95 \%$ KI $0,8-0,9$, $\mathrm{p}<0,001)$. Ved ST-elevasjonsinfarkt var det også kjønnsforskjell i overlevelse i aldersgruppen $\geq 80$ år, men etter justering for alder var forskjellen ikke lenger til stede (aldersjustert HR 1,0, $95 \%$ KI 0,9-1,2, p = 0,79).

\section{Diskusjon}

Denne studien av kjønnsforskjeller i utredning, behandling, komplikasjoner og overlevelse hos pasienter med hjerteinfarkt behandlet ved alle norske sykehus i perioden 2013-14 viser at koronar angiografi ble utført hos færre kvinner enn menn, men ved funn av koronare stenoser ble perkutan koronar intervensjon utført i tilnærmet samme grad hos begge kjønn. Spesielt ved ikke-ST-elevasjonsinfarkt ble kvinner utskrevet fra sykehus med færre sekundærprofylaktiske medikamenter enn menn. Det forelå få forskjeller i forekomsten av komplikasjoner og i overlevelse mellom kvinner og menn.

De internasjonale retningslinjene for behandling av hjerteinfarkt (24-26) anbefaler tidlig koronar angiografi til alle pasienter med hjerteinfarkt. Likevel viser denne studien at mange pasienter, og spesielt de med ikke-ST-elevasjonsinfarkt, ikke fikk tilbud om slik utredning og følgelig heller ikke mulighet for perkutan koronar intervensjon. 
Dette gjaldt flere kvinner enn menn. Disse nasjonale data fra 2013 og 2014 viser samme funn som beskrevet fra Ullevål i perioden 2006-07 (22) og av Melberg og medarbeidere i 2005 (23). Tilsvarende kjønnsforskjell er også nylig publisert i en fransk landsomfattende registerstudie (12).

Nytteverdien av invasiv utredning og behandling er ikke like godt dokumentert hos kvinner som hos menn $(31,32)$, og dette kan ha hatt betydning for valg av behandlingsstrategi. Flere tilleggssykdommer hos kvinnene kan også bidra til å forklare noe av kjønnsforskjellene. Vi har i denne studien ikke undersøkt om det forelå forskjeller på sykehusnivå - ulike lokale behandlingstradisjoner kan også ha hatt betydning. Det er tidligere vist at flere pasienter med hjerteinfarkt ble invasivt utredet dersom de ble innlagt i sykehus der det var tilbud om koronar angiografi (23).

Eventuelle ulikheter når det gjelder symptomer og kliniske funn ved mistanke om hjerteinfarkt hos kvinner og menn kan ikke forklare forskjellene, siden kun pasienter med diagnosen hjerteinfarkt ble registrert $\mathrm{i}$ Norsk hjerteinfarktregister og følgelig ble inkludert $\mathrm{i}$ denne studien. Vi finner grunn til å presisere at retningslinjene fra European Society of Cardiology, som er anbefalt brukt i Norge, ikke skiller mellom kvinner og menn $\mathrm{i}$ anbefalingene for invasiv utredning og behandling av hjerteinfarkt (24-26).

Sekundærprofylaktiske medikamenter som acetylsalisylsyre, ADP-reseptorhemmere og statiner er viktige for å forhindre reinfarkt og ytterligere ateroskleroseutvikling og anbefales for alle etter hjerteinfarkt (24-26). Årsaken til at noen pasienter, spesielt kvinner med ikkeST-elevasjonsinfarkt, likevel ikke fikk disse medikamentene ved utskrivning fra sykehus, er ikke klar. Mindre bruk av dobbel platehemming kan ha sammenheng med lavere andel perkutan koronar intervensjon hos kvinner, men retningslinjene anbefaler dobbel platehemming uavhengig av om det gjøres perkutan koronar intervensjon eller ikke. Flere tilleggssykdommer og følgelig økt risiko for komplikasjoner og bivirkninger av medikamentene hos kvinner kan også ha hatt betydning, særlig gjelder det de eldste pasientene.

De fleste tidligere studier viser ikke forskjeller i overlevelse hos kvinner sammenliknet med menn i ulike aldersgrupper etter hjerteinfarkt, men enkelte studier har vist lavere overlevelse etter hjerteinfarkt hos kvinner, spesielt ved ST-elevasjonsinfarkt $(15-21,33,34)$. Høy andel invasiv utredning og behandling også hos kvinner med ST-elevasjonsinfarkt kan være medvirkende til at vi ikke fant tilsvarende kjønnsforskjeller i denne studien.

Det foreligger noen begrensninger ved Norsk hjerteinfarktregister og denne data- analysen. Kun hjerteinfarkt som førte til innleggelse i sykehus ble registrert. Vi manglet oversikt over tilfeller av hjerteinfarkt som ikke førte til innleggelse og over pasienter som døde av hjerteinfarkt utenfor sykehus. Noen få sykehus leverte ikke fullstendige data gjennom hele perioden. Alle sykehus ble bedt om å sikre at alle tilfeller var registrert via egne pasientadministrative systemer, men Norsk hjerteinfarktregister hadde ikke mulighet til å kontrollere dette på lokalt nivå. Dekningsgraden sammenliknet med Norsk pasientregister er imidlertid god. Opplysninger fra flere sykehus i samme pasientforløp ble koblet i registeret. Dette medførte en viss grad av usikkerhet, spesielt ved ulik registrering av samme variabel.

Denne landsomfattende studien basert på innrapporteringer til Norsk hjerteinfarktregister av hjerteinfarkt i Norge i 2013-14 viser at det forelå få forskjeller når det gjelder invasiv behandling, komplikasjoner og overlevelse mellom kvinner og menn med hjerteinfarkt, men at kvinner i mindre grad enn menn ble utredet med koronar angiografi og i mindre grad anbefalt sekundærprofylaktisk medikasjon.

Norsk hjerteinfarktregister ønsker å bidra til bedring av hjerteinfarktbehandlingen i Norge. Gjennom å påpeke forskjeller mellom norsk praksis og aksepterte behandlingsanbefalinger håper vi nettopp å bidra til lik og god behandling av alle pasienter med hjerteinfarkt.

\section{Jarle Jortveit (f. 1974)}

er ph.d., spesialist i indremedisin og i hjertesykdommer, overlege og medlem av den faglige rådgivingsgruppen i Norsk hjerteinfarktregister. Forfatter har fylt ut ICMJE-skjemaet og oppgir ingen interessekonflikter.

\section{Ragna Elise Støre Govatsmark (f. 1977)}

er ph.d.-kandidat og daglig leder i Norsk hjerteinfarktregister

Forfatter har fylt ut ICMJE-skjemaet og oppgir ingen interessekonflikter.

\section{Jørund Langørgen (f. 1957)}

er ph.d., spesialist i indremedisin, i hjertesykdommer og i lungesykdommer, overlege og leder av den faglige rådgivingsgruppen i Norsk hjerteinfarktregister.

Forfatter har fylt ut ICMJE-skjemaet og oppgir ingen interessekonflikter.

\section{Torstein Hole (f. 1957)}

er dr.med., spesialist $\mathrm{i}$ indremedisin og i hjertesykdommer, klinikksjef, førsteamanuensis og medlem av den faglige rådgivingsgruppen i Norsk hjerteinfarktregister.

Forfatter har fylt ut ICMJE-skjemaet og oppgir ingen interessekonflikter.

\section{Jan Mannsverk (f. 1960)}

er spesialist i indremedisin og i hjertesykdommer, overlege og medlem av den faglige rådgivingsgruppen i Norsk hjerteinfarktregister. Forfatter har fylt ut ICMJE-skjemaet og oppgir ingen interessekonflikter.

\section{Siv Olsen (f. 1977)}

er ph.d.-kandidat, leder for NSFs landsgruppe av kardiologiske sykepleiere og medlem av den faglige rådgivingsgruppen i Norsk hjerteinfarktregister.

Forfatter har fylt ut ICMJE-skjemaet og oppgir ingen interessekonflikter.

\section{Cecilie Risøe (f. 1952)}

er dr.med., spesialist i indremedisin og i hjertesykdommer, overlege og medlem av den faglige rådgivingsgruppen i Norsk hjerteinfarktregister.

Forfatter har fylt ut ICMJE-skjemaet og oppgir ingen interessekonflikter.

\section{Sigrun Halvorsen (f. 1958)}

er dr.med., spesialist i indremedisin og i hjertesykdommer, avdelingsleder, professor og medlem av den faglige rådgivingsgruppen i Norsk hjerteinfarktregister

Forfatter har fylt ut ICMJE-skjemaet og oppgir ingen interessekonflikter.

\section{Litteratur}

1. Jortveit J, Govatsmark RE, Digre TA et al. Hjerteinfarkt i Norge i 2013. Tidsskr Nor Legeforen 2014 134: $1841-6$

2. Lawesson SS, Alfredsson J. Fredrikson $\mathrm{M}$ et al. A gender perspective on short- and long term mortality in ST-elevation myocardial infarction a report from the SWEDEHEART register. Int J Cardiol 2013: 168: 1041-7

3. Bucholz EM, Butala NM, Rathore SS et al. Sex differences in long-term mortality after myocardial infarction: a systematic review. Circulation 2014; 130: 757-67.

4. Egiziano G, Akhtari S, Pilote $L$ et al. Sex differences in young patients with acute myocardial infarction. Diabet Med 2013; 30: e108-14

5. Leurent G, Garlantézec R, Auffret V et al. Gender differences in presentation, management and inhospital outcome in patients with ST-segment elevation myocardial infarction: data from 5000 patients included in the ORBI prospective French regional registry. Arch Cardiovasc Dis 2014; 107: 291-8.

6. Dreyer RP, Beltrame JF, Tavella R et al. Evaluation of gender differences in Door-to-Balloon time in ST-elevation myocardial infarction. Heart Lung Circ 2013; 22: 861-9.

7. Milcent C, Dormont B, Durand-Zaleski I et al. Gender differences in hospital mortality and use of percutaneous coronary intervention in acute myocardial infarction: microsimulation analysis of the 1999 nationwide French hospitals database. Circulation 2007: 115: 833-9.

8. Anand SS, Xie CC, Mehta S et al. Differences in the management and prognosis of women and men who suffer from acute coronary syndromes. Journal of the American College of Cardiology 2005; 46 : $1845-51$

9. Johnston N, Jönelid B, Christersson C et al. Effect of Gender on Patients With ST-Elevation and Non-STElevation Myocardial Infarction Without Obstructive Coronary Artery Disease. Am J Cardiol 2015: 115 1661-6. 
10. Canto JG, Rogers WJ, Goldberg RJ et al. Association of age and sex with myocardial infarction symptom presentation and in-hospital mortality. JAMA 2012; 307: 813-22

11. Hvelplund A, Galatius S, Madsen M et al. Women with acute coronary syndrome are less invasively examined and subsequently less treated than men. Eur Heart J 2010; 31: 684-90.

12. Donataccio MP. Puymirat E, Parapid B et al. In-hospital outcomes and long-term mortality according to sex and management strategy in acute myocardial infarction. Insights from the French ST-elevation and non-ST-elevation Myocardial Infarction (FAST-MI) 2005 Registry. Int J Cardiol 2015; 201: 265-70.

13. Mehta LS, Beckie TM, DeVon HA et al. Acute Myocardial Infarction in Women: A Scientific Statement From the American Heart Association. Circulation 2016; 133: 916-47

14. Sulo E, Vollset SE, Nygård 0 et al. Trends in 28-day and 1-year mortality rates in patients hospitalized for a first acute myocardial infarction in Norway during 2001-2009: a «Cardiovascular disease in Norway» (CVDNOR) project. J Intern Med 2015; 277: 353-61.

15. Mannsverk J, Wilsgaard T, Njølstad I et al. Age and gender differences in incidence and case fatality trends for myocardial infarction: a 30-year followup. The Tromso Study. Eur J Prev Cardiol 2012; 19: $927-34$

16. Langørgen J, Igland J, Vollset SE et al. Short-term and long-term case fatality in 11878 patients hospitalized with a first acute myocardial infarction. 1979-2001: the Western Norway cardiovascular registry. Eur J Cardiovasc Prev Rehabil 2009; 16 : 621-7.

17. Maclntyre K, Stewart S, Capewell S et al. Gender and survival: a population-based study of 201,114 men and women following a first acute myocardial infarction. J Am Coll Cardiol 2001; 38: 729-35.

18. Parashar S, Rumsfeld JS, Reid KJ et al. Impact of depression on sex differences in outcome after myocardial infarction. Circ Cardiovasc Qual Outcomes 2009; 2: 33-40.
19. Jneid H, Fonarow GC, Cannon CP et al. Sex differences in medical care and early death after acute myocardial infarction. Circulation 2008; 118 : 2803-10.

20. Simon T, Mary-Krause M, Cambou JP et al. Impac of age and gender on in-hospital and late mortality after acute myocardial infarction: increased early risk in younger women: results from the French nation-wide USIC registries. Eur Heart J 2006; 27: 1282-8.

21. Bonarjee VV, Rosengren A, Snapinn SM et al. Sexbased short- and long-term survival in patients following complicated myocardial infarction. Eur Heart J 2006; 27: 2177-83.

22. Halvorsen S, Eritsland J, Abdelnoor M et al. Gender differences in management and outcome of acute myocardial infarctions treated in 2006-2007. Cardiology 2009; 114: 83-8.

23. Melberg T, Thoresen M, Hansen JB et al. Hvordan behandles pasienter med akutt koronarsyndrom inorske sykehus? Tidsskr Nor Lægeforen 2005; 125: 2925-8.

24. Cornel JH, Becker RC, Goodman SG et al. Prior smoking status, clinical outcomes, and the comparison of ticagrelor with clopidogrel in acute coronary syndromes-insights from the PLATele inhibition and patient Outcomes (PLATO) trial. Am Heart J 2012; 164: 334-342.e1.

25. Möllmann H, Liebetrau C, Nef HM et al. The Swedish paradox: or is there really no gender difference in acute coronary syndromes? Eur Heart J 2011; 32: 3070-2.

26. Roffi M, Patrono C, Collet JP et al. 2015 ESC Guidelines for the management of acute coronary syndromes in patients presenting without persistent ST-segment elevation: Task Force for the Management of Acute Coronary Syndromes in Patients Presenting without Persistent ST-Segment Elevation of the European Society of Cardiology (ESC). Eur Heart J 2016; 37: 267-315

27. FOR 2011-12-16 nr 1250: Forskrift om innsamling og behandling av helseopplysninger i Nasjonalt register over hjerte- og karlidelser (Hjerte- og karregisterforskriften). 2011. www.lovdata.no/ cgi-wift/ldles?doc=/sf/sf/sf-20111216-1250.html (15.6.2016)

28. LOV 2001-05-18 nr 24: Lov om helseregistre og behandling av helseopplysninger (helseregisterloven). 2001. www.lovdata.no/all/tl-20010518-024002.html (15.6.2016).

29. Thygesen K, Alpert JS, Jaffe AS et al. Third universal definition of myocardial infarction. Eur Heart J 2012; 33: 2551-67.

30. Aakre KM, Rotevatn S, Hagve TA et al. Nasjonale anbefalinger for tolkning av troponinverdier ved diagnostikk av akutt hjerteinfarkt. Tidsskr Nor Legeforen 2013; 133: 2241-2.

31. Lagerqvist $B$, Säfström $K$, Ståhle $E$ et al. Is early invasive treatment of unstable coronary artery disease equally effective for both women and men? FRISC II Study Group Investigators. J Am Coll Cardiol 2001; 38: 41-8

32. Clayton TC, Pocock SJ, Henderson RA et al. Do men benefit more than women from an interventional strategy in patients with unstable angina or non-ST-elevation myocardial infarction? The impact of gender in the RITA 3 trial. Eur Heart J 2004; 25: $1641-50$.

33. Kvakkestad KM, Abdelnoor M, Claussen PA et al. Long-term survival in octogenarians and older patients with ST-elevation myocardial infarction in the era of primary angioplasty: A prospective cohort study. Eur Heart J Acute Cardiovasc Care 2016; 5: 243-52.

34. Tegn N, Abdelnoor M, Aaberge L et al. Invasive versus conservative strategy in patients aged 80 years or older with non-ST-elevation myocardial infarction or unstable angina pectoris (After Eighty study): an open-label randomised controlled trial. Lancet 2016; 387: 1057-65.

Mottatt 7.3. 2016, første revisjon innsendt 22.5. 2016, godkjent 15.6. 2016. Redaktør: Tor Rosness. 